\title{
GLACIAL LAKE OUTBURST FLOOD IN NEPAL: A CHALLENGING ENVIRONMENTAL HAZARD AND DISASTER
}

\author{
Shiva Kant Dube \\ Department of Geography, TU, Thakur Ram Multiple Campus, Birgunj, Nepal \\ Email: shivakant.dube@gmail.com
}

\begin{abstract}
Geographically, Nepal is situated on the lap of the Himalayas occupying 0.3 percent area of Asia and 0.03 percent of the world. Recently, global climate change has invited enormous environmental hazards and disasters in the Hindu-Kush Himalayan region. Catastrophic floods originating from the outburst of glacial lakes have been recognized as one of the primary natural hazards in Nepal, making downstream areas vulnerable. Frequent severe floods caused by glacier outburst in the Nepal Himalayas, occur once every three years. Nine potentially dangerous glaciers were identified in the Eastern and Central Himalayas during pre- and post-monsoon seasons. At national and international level, Glacial Lake Outburst Floods (GLOF) in Nepal, are receiving considerable attention. Such floods endanger thousands of people, hundreds of villages and basic infrastructure causing disasters. This paper incorporates a case of flash-flood caused by GLOF and torrential rain in India which can be taken as a lesson to mitigate/minimize massive loss of lives and property in the Nepalese context.
\end{abstract}

\section{Key words}

Glacial lake outburst flood (GLOF); environmental hazards; environmental disasters; vulnerable; flash-flood; massive loss

\section{Introduction}

Those events or accidents, whether caused by natural processes or human factors, are called extreme events which occur very rarely and aggravate natural environmental processes to cause disaster for human society such as sudden tectonic movements leading to earthquake and volcanic eruption, continued dry conditions leading to prolonged droughts, floods, atmospheric disturbances, glacial lake outburst floods, collision of celestial bodies etc. Environmental hazards may be defined as those extreme events either natural or man-induced, which exceed the tolerable 
magnitude within or beyond certain time limits, make adjustment difficult, result in catastrophic losses of property, income and lives and become the headlines of different news media at world level (Strahler \& Strahler, 1976).

Hazards are generally taken to be the processes, both natural and anthropogenic, which cause an accident/extreme event or danger whereas 'disaster' is a sudden adverse or unfortunate extreme event which causes great damage to human beings as well as plants and animals. Disasters occur rapidly, instantaneously and indiscriminately. It, therefore, becomes obvious that environmental hazards are the processes whereas the environmental disasters are the results or responses of environmental hazards. It may be mentioned that environmental disasters are always viewed in terms of human beings. The intensity of environmental disaster is weighed in terms of the quantum of damages done to the human society (Singh, 1999).

It is also important to note that environmental hazards are not always destructive and disastrous themselves rather it is the effects of these events on other natural processes which become disastrous. For example, the Tajik area of the then southern U.S.S.R. 'is seismically a highly active region, shaken by upwards of 3000 tremors a year but these caused few direct causalities'. But 'the Tajik earthquake in the then south of the U.S.S.R. on 21 January, 1989 , for example, was only of magnitude 5.5, but its timing unfortunately coincided with highly unstable slope conditions caused by high pore-water pressure resulting from snow-melt' (Embleton, 1989) and thus it became disastrous.

Glacial lake outburst flood (GLOF) is one of those extreme events caused due to natural or anthropogenic or by both factors. This paper incorporates the introduction of environmental hazard, environmental disaster, glacial lake outburst floods, definition, causes, effect, impact, distribution, study and research, hazards record, investigation report of Imja glacier lake, a case of India, mitigation measures and retreat of glacial lake including conclusion.

\section{Glacial lake outburst flood}

Geographically, Nepal is situated on the lap of the Himalayas in southern Asia, sandwiched between two large countries, China in north and India in south, east and west, occupy an area of $1,47,181$ sq. kilometers which is about 0.3 percent of Asia continent and 0.03 percent of world land mass. Situated on the southern slope of the Himalayas, it stretches in between the latitudes $26^{\circ} 22^{\prime}$ and $30^{\circ} 27^{\prime}$ north and the longitude $80^{\circ}$ o4 and $88^{\circ} 12^{\prime}$ East (Chaudhary, 1998). According to recent population census report Himalayan region habituates with 6.73 percent, Hilly region 43 percent and Terai region habituates with 50.27 percent population of Nepal (CBS, 2011). These regions are more vulnerable from the point view of GLOF.

Lakes are large bodies of impounded water. There are many causes for the formation of lakes, melting of glaciers is one of them. Glaciers are moving bodies of ice. They move down-slope just like water in a river. The glaciers on their way down erode the valley in which they flow and accumulate the eroded materials (called moraine) in their front and side. As the glacier reaches a point in the glacier valley where the air temperature is above $0^{\circ} \mathrm{C}$ the glacier starts to melt. The water that is formed due melting of the glacier is blocked by end moraine (moraine present at the tip of the glacier) and starts accumulating. As the melting process continues more water leads to the formation of lakes (Sharma \& Bhatta, 2008).

The moraines are sediments produced during erosive activity of glaciers and are very loose. But the ice present in between moraine acts as a binding agent for moraine and makes it strong. The end moraine due to presence of 
ice acts as a dam and blocks the flow of water (Gurung, 2007).

As water accumulation increases the lake starts to become larger and larger. This increasing volume of water pushes the end moraine with increasing force. If the accumulation of water mass is very high the end moraine may break due to very high force exerted by water, releasing a huge amount of water that was stored during centuries. This creates a flood termed as GLOF i.e. Glacial Lake Outburst Flood (Sharma \& Bhatta, 2011).

\section{Definition}

Glacier lake outburst floods (GLOFs) refer to sudden and in some cases cyclic release of melt water from a glacier-dammed or moraine-dammed lake, which can result in a catastrophic flood. Thorarinsson (1939) introduced the term "jökulhlaup" for glacial floods due to the cataclysmic drainage of subglacial lakes in Iceland. It was originally used to refer outburst floods triggered by volcanic activity and subsequently transferred to a variety of other types of glacial floods. It has become a widely used synonym for describing catastrophic glacial floods in general. The size of glacial lakes varies considerably and the lakes may hold up to tens of millions of cubic meters of water. Glacier lake outbursts produce flows of water that may be an order of magnitude greater than average rainfall (as cited by Singh \& Haritashya, 2008).

\section{Causes}

Recently, global climate change is considered to be the root cause for all types of environmental hazards and global issues caused due to natural and anthropogenic activities. Climate change refers to the variation in the Earth's global climate or in regional climates over time. United Nations Framework Convention on Climate Change (UNFCCC, 2001) defines this as "a change of climate which is attributed directly or indirectly to human activity that alters the composition of the global atmosphere". Out of all natural hazards glacial lake outburst flood is one originating from high Himalayan region inviting devastation and destruction towards downstream area.

\section{Effect}

Many of the effects of GLOF are just like those caused by flood. But there are certain features that are typical of GLOF only. Unlike the case with flood caused by rainfall, a huge amount of water is released at once during a GLOF. This gives a very high unusual flood called flash-flood, which has very high kinetic energy and sweeps away everything in its way. So, the effect of GLOF will be very destructive and of very high magnitude. Another characteristic is that, in rainfall caused flood, the flood level increases slowly, but in the case of GLOF, water is released instantaneously and flooding is immediate. This does not give opportunity for people to shift their property and themselves. So, the GLOF is most destructive type of flood.

\section{Melting glacier and its impact}

Studies have shown that Nepal's temperature increases 0.04-0.06 degree Celsius annually. Himalayan glacier melt and retreat have been documented by various studies. Fifteen Glacial Lake Outburst Floods (GLOF) events have been documented in Nepal (Ives, 1986). The most recent event occurred in 1985, when Dig Tsho, a lake in the headwaters of the Koshi River, breached after an avalanche slid into the river, overtopping the dam. The event destroyed hydro-electricity projects, bridges, houses and farm land not only in Nepal, but also in Bihar state of India (NCVST, 2009).

A phenomenal change in the Himalayas in terms of climate would be a catastrophe across South Asia. It is not just the future of a few mountain communities at stake, but the lives of nearly 1 in 4 people in the world, all of whom rely on the Himalayas for water. Nepali rivers alone provide water for 700 million people in India and Bangladesh. If there is less snow in the Himalayas, or the monsoon rains weaken, or the glaciers melt with climate change, then 
all South Asian farming, industries, water supplies and cities will suffer (SAAPE, 2010).

Floods endanger thousands of people, hundreds of villages, and basic infrastructure such as trails and bridges. The flood risk is also a major impediment to hydroelectric development in several river basins. Unlike most other mountain hazards in Nepal, reducing the possibility of outburst floods is technically feasible. The first attempt to reduce the hazard of one lake by artificially lowering its water level was partially completed in June 20oo. Completing this task and beginning work on other hazardous lakes will require difficult decisions about risk by downstream residents and substantial investment from the international aid community (Kattelmann, 2003).

\section{Distribution of glacial lakes in Nepal}

The northern part of Nepal is covered by high Himalayas which are part of the HinduKush Himalayan region consisting of many glaciers. These glaciers melt and form glacial lakes. At present, there are many glaciers with few gaps in the northern belt of Nepal (Fig. 1). But potentially dangerous glacial lakes are situated in the eastern part of Nepal, in Sapta Koshi River basin (Sharma \& Bhatta, 2008).

Catastrophic floods originating from the outburst of glacial lakes have recently

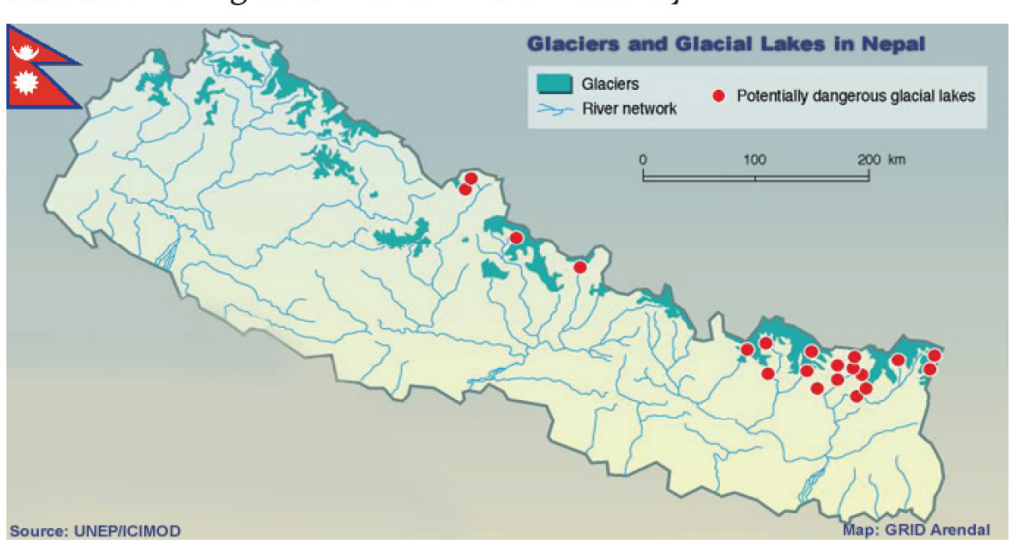

Fig. 1 Distribution of glacier and glacial lakes in Nepal recognized as one of the primary natural hazards in Nepal. Although other natural disasters such as rainfall-floods, earthquake, landslides, wildfires, and epidemics have claimed the lives of thousands of Nepalese in recent decades (Oi, 1993; Poudyal-Chhetri, 1999), glacial-lake outbursts are feared for the potential devastation from a single large event. Following a destructive flood in the Khumbu Himal of eastern Nepal in 1985, several studies and inventories of Himalayan glacial lakes have been conducted, and the hazard is becoming known to agency professionals, politicians and the general public. The Nepali press has carried dozens of articles in recent years, and stories about glacial lakes occasionally appear in international publications ranging from the New York Times (Wilford, 1988) to New Scientist (Pearce, 1999). As awareness of glacial lake outburst floods grows, people at risk along with technical experts and potential donors need to decide whether to pursue strategies to actively reduce the hazards posed by these lakes (as cited by Kattelmann, 2003).

\section{Study and research about glacial lakes and outburst floods}

Most of the perennial rivers in Nepal originate from the high Himalayas and they are fed in large amounts by melt water of snow and glacier ice. Snow and glaciers are important water resources in Nepal. While liquid precipitation (rain) is directly discharged

through a river in a relatively short period, solid precipitation (snow) accumulates on theground and melts gradually. The melt water from snow and ice contribute significantly to the sustained base flow of mountain areas throughout the dry period of the year. The sustained base flow is important for water resources planning and management.

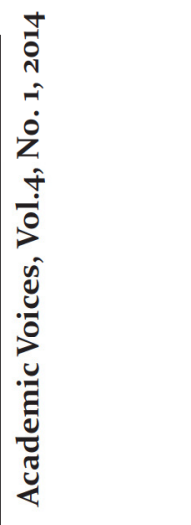


However, theglacier-fed river has one serious problem, the potential flood that may be caused by an outburst of a glacier lake. A glacier lake outburst flood (GLOF) is one of the major natural hazards in Nepal. Most of the glacier lakes in Nepal Himalayas are embanked by a moraine formed in the previous neo-glaciation period. The moraine dam structure is often not consolidated and unstable. The breach of a moraine dam and the catastrophic outflow of the lake create serious problems for the infrastructure, in addition

\section{Glacier Lake Outburst Floods}

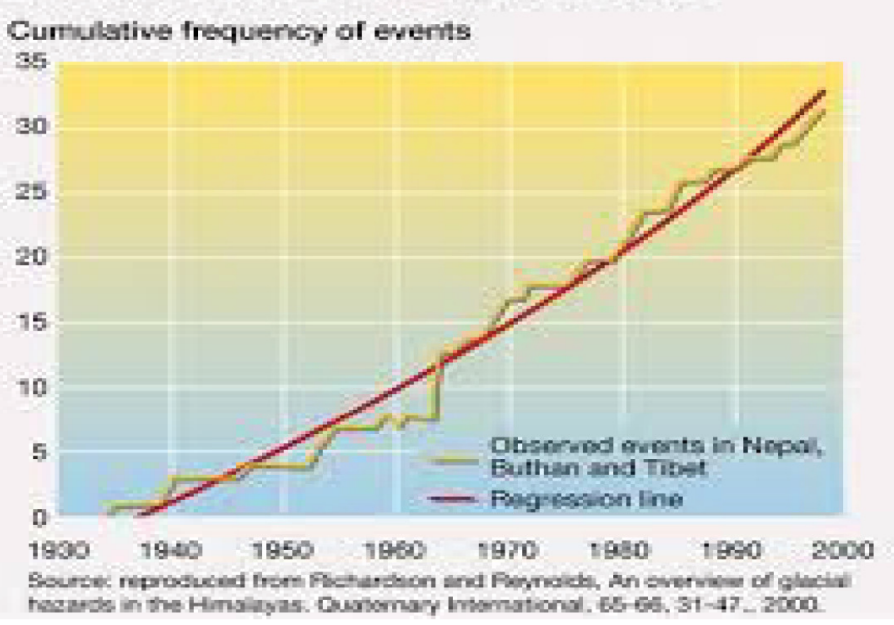

Fig. 2 Frequency of glacial lake outburst floods to the inhabitants in the downstream areas (Yamada, 1991).

Therefore, GLOF-control is especially important for the development of water resources in Nepal. In order to control the hazard, one has to first get enough information and knowledge on a glacier lake in the Himalayas. Very little, however, is known. Since the basic information such as location, number and type of glacier lakes in Nepal Himalayas still remains incomplete, a flight observation of glacier lakes and their mother glaciers was carried out on a reconnaissance basis in 1991 (Yamada, 1991). As a result of the observation, potentially dangerous glacier lakes were found at many places in the Himalayas. For obtaining detailed information of a glacier lake, Imja Glacier Lake in Khumbu district was chosen as one of the dangerous glacier lakes in the Nepal Himalayas. A site visit to the lake was made in the pre-monsoon season from the end of March to the beginning of April, 1992 (Yamada, 1992).

\section{Hazards record of glacier lake outburst flood in Nepal}

Table 1 shows a recent history of the flood hazards derived from the outbursts of glacier lakes compiled from various papers and reports prepared by previous investigators and engineers (Ives, 1986, Water and Energy Commission Secretariat, 1987 and Lanzhou Institute of Glaciology and Geocryology, Water and Energy Commission Secretariat and Nepal Electricity Authority, 1988). The distribution of the outburst of lakes in the past is illustrated. However, the records are only available for a part of Eastern and Central Nepal Himalayas, because no systematic inspection has been carried out yet for all over the Nepal Himalayas. More records may be added to this list if inspection progresses in the future (Yamada, 1992).

Except for records 8, 14 and 16, the data of outburst lakes listed were obtained after 1960. The older records may be incomplete for several reasons; the information may be lost from the memory of the inhabitants and also from the natural features in a river bed. But in the thirty years since 196o, thirteen GLOFs were counted, which is a very high frequency when compared with other natural hazards. GLOF in Nepal Himalayas happened more than once per every three years (Fig. 2). 
Table 1 Hazards record of glacial lakes in Nepal

\begin{tabular}{|c|c|c|}
\hline S. No. & \multicolumn{2}{|c|}{ Sapta Koshi river system } \\
\hline & \multicolumn{2}{|c|}{ Tamur Khola } \\
\hline 1. & 1980 & $\begin{array}{l}\text { Phucan Glacier Lake. Water level rising } 20 \mathrm{~m} \text {. including heavy } \\
\text { debris of big rocks etc. damaging forest, river bed etc. }\end{array}$ \\
\hline \multicolumn{3}{|c|}{ Arun River (Pumqu River in Tibet) } \\
\hline 2. & $\begin{array}{|ll|}21 & \text { September, } \\
1964 & \\
\end{array}$ & $\begin{array}{l}\text { Gelhaipco lake outburst. End moraine collapse due to glacier-fall } \\
\text { into lake. Damaging road, } 12 \text { trucks etc. }\end{array}$ \\
\hline $3,4,5$ & 1968, 1969, 1970 & $\begin{array}{l}\text { Ayico lake. GLOF occurred three times at the same glacier lake. } \\
\text { Damaging road, bridges etc. }\end{array}$ \\
\hline 6. & 27 August, 1985 & $\begin{array}{l}\text { Jinco lake. Moraine collapse due to glacier sliding into lake. } \\
\text { Damaging eight villages, livestock, cultivation field, roads, bridges } \\
\text { etc. }\end{array}$ \\
\hline 7 . & around 1964 & $\begin{array}{l}\text { GLOF noticed by local people along the Arun river. Timber, } \\
\text { concrete block and parts of trucks flowing down. }\end{array}$ \\
\hline 8. & Unknown & $\begin{array}{l}\text { GLOF along the Barun Khola. Some traces of past GLOF on the } \\
\text { river channel recognized from aerial survey. }\end{array}$ \\
\hline \multicolumn{3}{|c|}{ Dudh Koshi River } \\
\hline 9. & 3 September, 1977 & $\begin{array}{l}\text { Nare Drangka Glacier Lake (South slope of Mt. Ama Dablam). } \\
\text { Ice-cored moraine collapsed damaging min-hydro plant, roads, } \\
\text { bridges, cultivation fields, etc. }\end{array}$ \\
\hline 10. & 4 August 1985 & $\begin{array}{l}\text { Dig Tsho. Moraine collapsed due to rock avalanche. Initial } \\
\text { discharge of } 2000 \mathrm{~m} 3 / \mathrm{s}^{-1} \text {. Destroying Namche hydropower plant } \\
\text { completely, damaging roads, bridges, cultivation fields, livestock, } \\
\text { houses, inhabitants, etc. }\end{array}$ \\
\hline \multicolumn{3}{|c|}{ Tama Koshi River } \\
\hline 11. & Mid-July 1991 & $\begin{array}{l}\text { Chubung Lake outburst at the end of Ripimo Shar Glacier damaging } \\
\text { houses, cultivation field at Beding village. }\end{array}$ \\
\hline \multicolumn{3}{|c|}{ Sun Koshi River (Poiqu River in Tibet) } \\
\hline 12. & 1964 & $\begin{array}{l}\text { Zhangzangbo Glacier Lake outburst. Moraine collapsed due to } \\
\text { seepage. Water level rising } 8 \mathrm{~m} \text {. }\end{array}$ \\
\hline 13. & 1981 & $\begin{array}{l}\text { The same lake above. Moraine collapse due to glacier calving. Initial } \\
\text { discharge of } 16, \text { ooo } \mathrm{m}_{3} / \mathrm{s} \text {. Damaging Arniko Highway, Friendship } \\
\text { Bridge, Sun Koshi hydropower plant, cultivation fields, livestock, } \\
\text { inhabitants, etc. }\end{array}$ \\
\hline 14. & August 1935 & $\begin{array}{l}\text { Taraco Glacier Lake. Ice-cored moraine collapsed due to seepage } \\
\text { damaging cultivation fields, livestock, etc. }\end{array}$ \\
\hline \multicolumn{3}{|c|}{ Narayani river system } \\
\hline \multicolumn{3}{|c|}{ Trisuli River } \\
\hline 15. & 1964 & Longda Glacier Lake outburst at Gyirongzangbo River basin. \\
\hline \multicolumn{3}{|c|}{ Seti Khola } \\
\hline 16. & 450 years ago & $\begin{array}{l}\text { Outburst of a glacier lake with the area of } 10 \mathrm{~km}^{2} \text { located behind } \\
\text { Machhapuchhare. Ice-cored moraine collapsed. } 50-60 \mathrm{~m} \text { thick } \\
\text { debris covering Pokhara basin. }\end{array}$ \\
\hline
\end{tabular}




\section{Aerial observation of glacier lakes in the Nepal Himalayas}

Since it is very difficult to gain access to glacier areas in the high Himalayan mountains, a flight observation was planned in the Eastern and Central parts of the Nepal Himalayas as the most effective measure. The aims of the flight observations were to inspect and to identify potentially dangerous glacier lakes and to record features of the mother glaciers and topographical condition in the vicinity of the lakes.

\section{Area of flight observations}

The flights were made in the Langtang Khola basin on 22 April 1991, and in Barun Khola basin, a tributary of Arun River, and Dudh Koshi basins including Honku and Hinku River basins on 25 April and in Chilime Khola basin, tributary of Trisuli River, and Marsyangdi River basins on 5 May. The glacier lakes identified did not include all of the lakes that may have been found in the above basins. The observations were limited because of the flight pattern taken through the basins and the cloudy condition during part of the flight course.

\section{Evaluation of dangerous glacier lakes}

The flight observation produced one set of oblique photos of glacier lakes and their mother glaciers along the flight courses. Using these photos the potentially dangerous glacier lakes are identified by consideration of \pm the following points:

(a) Dam material condition,

(b) Size of the lake,

(c) Topographical features in the vicinity of the lake

If the dam material is composed of loose moraine, the dam may be easily broken. The degree of solidification of a dam is determined by evaluating whether it is fresh or not by means of the vegetation cover on it and its color.

Glacier lakes are often dammed by ice-cored moraines. As the ice-core gradually melts, the dam decreases in its level and is weakened. Ice-cored dams are evaluated by the features of an end moraine.

A large amount of stored water in a glacier lake poses an extremely serious hazard. Therefore, ground surveys have to be carried out in the future for measuring the depth of a lake. At present only the area of a lake is employed as an evaluation criterion of hazardous glacier lakes.

A glacier lake surrounded by steep slope(s) has a chance to incur snow, ice and rock avalanches into the lake. If the glacier has a cliff in the terminus and it contacts with the lake, the carving and sliding of the glacier will help trigger the dam burst (Yamada, 1992).

\section{Dangerous glacier lakes in the Nepal Himalayas}

The identified dangerous glacier lakes are listed as follows. All the lakes were formed in the terminus of their mother glaciers and are dammed by lateral and end moraines.

\section{Barun Khola drainage basin, a tributary of the Arun River}

1. Lower Barun Glacier lake dammed by ice-cored moraine on the terminus of Lower Barun Glacier, which is located in the upper reach of the Barun Khola. The glacier lake contacts with cliff shaped glacier end, which is stagnant and covered with thick debris. Because of heavy cloud and dangerous turbulence during the flight, only two glaciers, namely Barun glacier lake and Lower Barun glacier lake, were observed in the Barun Khola (river) drainage basin.

\section{Dudh Koshi drainage basin}

2. Chamlang Tsho and three nameless 
glacier lakes formed on the terminus of both nameless glaciers flowing down from the mountains in the left bank side of the Hunku river, a tributary of the Dudh Koshi. Both the lakes are now separated from the mother glaciers.

3. Nameless. The biggest one among the four glacier lakes formed in front of Naulekh Glacier located in the right bank side of the Hunku River. The lake is separated from the glacier. Because of cloud and turbulence, the flight was made only partially along the Hunku River. Though 14 glacier lakes were visible in the basin, 10 glacier lakes were taken in photos. Panchi Pokhari glacier lakes in the uppermost reach of the Hunku River were fully covered by thick snow, and were thus quite difficult to evaluate.

4. Sabai Tsho formed on the terminus of Sabai Glacier in the upper reach of the Hinku River, a tributary of the Dudh Koshi. The very steep mother glacier approaches the lake.

5. Dudh Kund, on the terminus of Sanu Glacier on the left bank side of the Hinku River. The lake is separated from the glacier.

6. Mojang Glacier Lake, on the terminus of Mojang Glacier is found on the left bank side of the Hinku River. It is not sure whether the glacier contacts with the lake or not. Fortunately, the Hinku River drainage basin could be completely flown over, and eight glacier lakes were found.

7. Imja Glacier Lake, on the terminus of Imja Glacier in the upper reach of the Imja Khola (river), an uppermost tributary of the Dudh Koshi. The glacier lake contacts with a cliff shaped glacier end, which is stagnant and covered with thick debris. The areas along the main stream of the Dudh Koshi, i.e. Khumbu region, were almost fully flown over and 21 glacier lakes were found.

\section{Tama Khola drainage basin}

8. Tsho Rolpa, is found on the terminus of Trambau Glacier in the upper reach of the Tama Khola (Rolwaling Chhu). The glacier lake contacts with a cliff shaped glacier end, which is stagnant and covered with thick debris (Fig. 3).

The characteristics of potential outburst floods from the Tsho Rolpa glacial lake due to two types of morainedam failure caused by seepage flow or water overtopping were analyzed with various scenarios by using integrated modeling system of three numerical models: (1) the flow and bed-surface erosion model, (2) the seepage model and (3) the slope stability model. Flood inundation areas were also identified by using the numerical model of the flow and moraine dam failure and geographical information system tools. Possible threats and damages due to the potential GLOF events from the lake were also analyzed based on numerical results, flood inundation maps and field investigations (Shrestha et al., 2013).

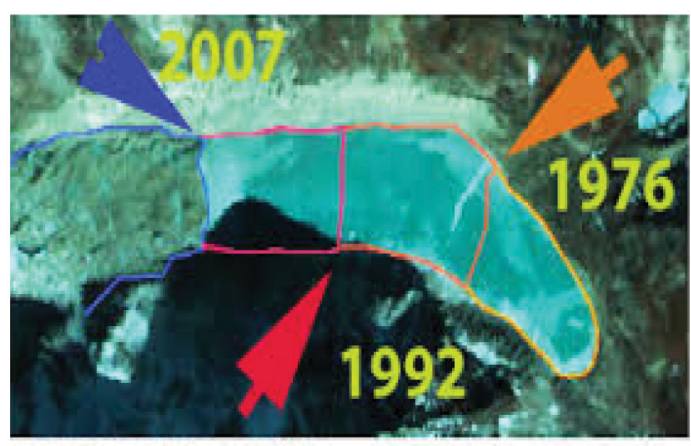

c. Lumding Glacier and Tho

Fig. 3 Enlargement of Tsho glacial lake

\section{Marsyangdi Khola drainage basin}

9. Thulagi Glacier Lake is situated on the terminus of Thulagi Glacier at the Southwest end of Mt. Manaslu. The glacier lake contacts with a cliff shaped glacier end, which is stagnant and covered with thick debris. 
The basin was also only partially flown over, covering areas in the Southern portions of Mt. Manaslu and extending to the uppermost reach of the Marsyangdi River. In addition to the above drainage basins, the full area of Langtang Khola drainage basin and partial areas of the Chilime Khola drainage basin were observed. Both the rivers are tributaries of the Trisuli River. Due to very poor development of glacier lakes in these regions, there were no dangerous lakes identified.

\section{Investigation of Imja Glacier Lake}

Imja Glacier Lake in the Khumbu region is located at the uppermost reach of the Imja Khola. It was chosen as a typical dangerous glacier lake for obtaining detailed information on these lakes. The observation was carried out from 1 to 5 April 1992.

\section{General features of Imja Glacier Lake}

The lake was covered by thick ice. Being as the ice measured $50 \mathrm{~cm}$, this was found to be safe enough to walk on around the lake. The lake developed on the end of the stagnant glacier tongue of Imja Glacier. The upper stream side of the lake touches on the cliff-shaped glacier end. The tongue area is covered by thick debris, which characterizes large glaciers in the Himalayas. The sides and lower stream areas of the lake are dammed by lateral and end moraines developed by past activities of Imja Glacier. The lateral moraines are quite high, assumed to be $70 \mathrm{~m}$ from the lake surface, though actual measurements were not made. The end moraine is relatively lower than the lateral moraines. The end moraine rises sharply up some $100 \mathrm{~m}$ above the river bed level of the Imja Khola. Lake water is being drained out to the Imja Khola through the small outlet on the end moraine, and the level of lake water is comparable to the lowest level of the end moraine (Yamada, 1992).

\section{A case of Kedarnath, India: Flash flood}

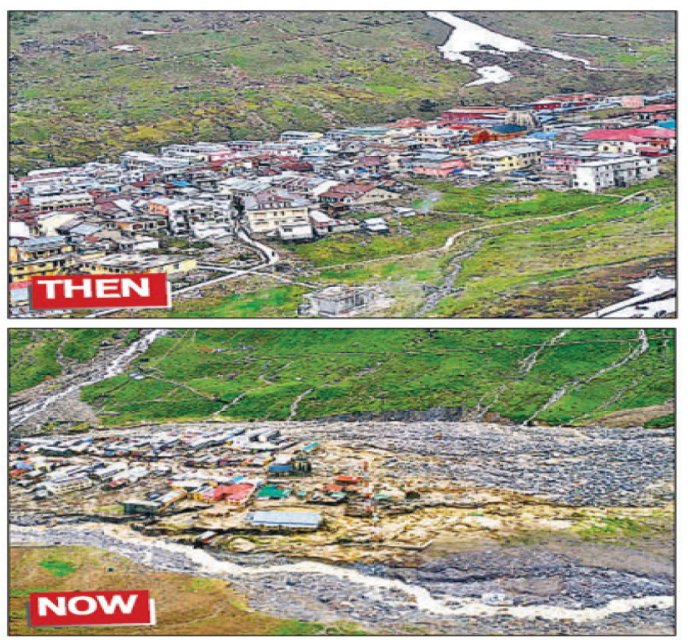

Fig. 4 Devastation of Kedarnath town by GLOF

Kedarnath town suffered extensive destruction during June 2013 from flash floods caused by torrential rains and GLOF in Uttarakhand state (Fig. 4). On June 16, 2013 at approximately 7:30 p.m., a landslide occurred near Kedarnath Temple with loud thunder followed by gushing of huge amount of waters from Chorabari Tal or Gandhi Tal down Mandakini River at about 8:30 p.m. which washed away everything in its path. On June 17, 2013 at approximately 6:40 a.m., waters rushed down River Saraswati and from Chorabari Tal or Gandhi Sarovar bringing along with its flow huge amount of silt, rocks and boulders. A huge boulder got stuck behind Baba Kedarnath Temple, protecting it from the ravages of the flood's fury. The flood water gushed on both sides of the temple destroying everything in its path. Thus in the middle of pilgrimage season, torrential rains, cloud bursts and resulting flash floods nearly destroyed the town of Kedarnath. The town was the worst affected area by the floods. Thousands of people were killed and thousands of others (mostly pilgrims) were reported missing or stranded due to landslides around Kedarnath. Although the surrounding area and compound of the Kedarnath temple were destroyed, the temple itself 
survived. The rescue operation resulted in more than 10o,ooo people being airlifted with the help of the Indian Army, Air force, NDRF and Indo-Tibet border police force. The Air Force dropped logs to build pyres for mass cremations of the victims. It was reported that previously uncollected bodies were still being found one year after the tragedy (Wikipedia, 2014).

\section{Mitigation measures of effect of GLOF}

Major perennial rivers of Nepal have originated from the Himalayas. These river basins have provided suitable habitat as well as sources of livelihood for their inhabitants. Many people are still depending upon these river basins for their survival. Therefore, it is urgent to plan, adopt and implement various techniques to control glacier lakes and mitigate the potential loss exerted by GLOF (Fig. 5). Some of techniques feasible for it can be adopted for welfare of the people in the downstream areas such as technical measures, management of pre-information and awareness related activities.

\section{Retreat of glacial lakes}

The monitoring result of Shorong Himal since 1978 shows that the retreat until 1989 was 30 $\mathrm{m}$, which is equivalent to $12 \mathrm{~m}$ thinning of the glacier surface. Recently it was resurveyed and the glacier surface has further retreated by 14 m after 1998.

Recent studies of seven clean type glaciers in Khumbu region for the 1970 to 1989 have documented that the majority of the glaciers have retreated in the range of 30 to $60 \mathrm{~m}$ in the observed period, while a subsequent expedition organized in 2004 found the majority of the glaciers in Khumbu region continuing to shrink at a rather fast rate, while some smaller glacier began to disappear. Similar trends have been documented in studies of the Yala glacier of Langtang region, while a survey in the Ghunsa Khola basin of Kanchnajanga area and a comparison of the 1992 glaciers with those of 1958 to 1992. The widespread glacial retreat in Nepal can have two direct consequences (i) changes in the hydrological regime, and (ii) glacial lake outburst floods (Adapted from Nepal's Strategic Program for Climate ResilienceConsultative Draft, 2010).

\section{Conclusion}

Environmental hazards are those extreme events either natural or man-induced, which exceed the tolerable limit resulting massive loss of lives and property causing disasters.

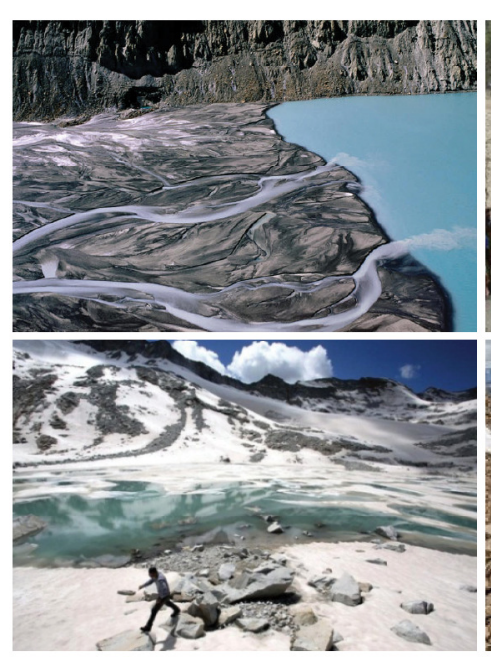

Fig. 5 Existing condition, melting, enlargement and outburst of glacial lakes of Nepal

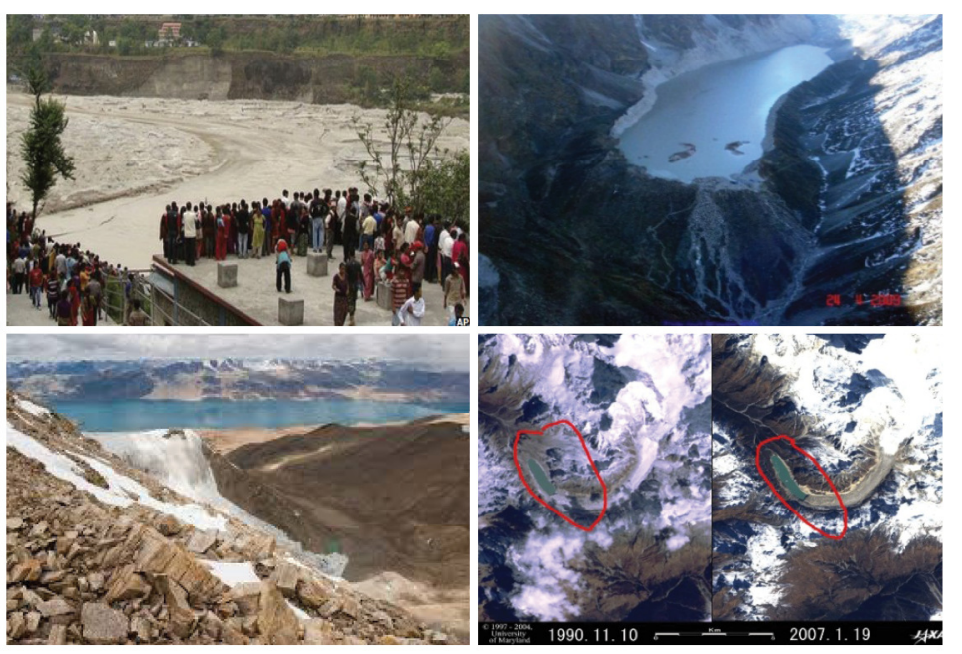

| 
Environmental hazards are the processes whereas Environmental disasters аге the responses of it. Glacial lake outburst flood (GLOF) is one of those extreme events caused due to natural or anthropogenic or by both factors. According to the records of GLOF in the Nepal Himalayas, thirteen GLOFs happened in the thirty years since 196o. The records show that the average frequency is more than once every three years, which is quite high in comparison with other natural hazards such as a typhoon, a tsunami, etc. GLOF can be concluded to be a rather common natural hazard in the Nepal Himalayas. The flight observation yielded sufficient information to identify dangerous glacier lakes, as expected. Nine potentially dangerous lakes were discovered in spite of the fairly limited areas in the basins which had been were planned to be observed. It is concluded that Imja Glacier Lake is one of the most dangerous glacier lakes in the Nepal Himalayas because of the huge amount of stored water, unstable icecored moraine and the relatively high density of population, including the many trekkers in the downstream area. This glacier lake has to be monitored constantly. Further full scale flight observation over the entire Nepal Himalayas may yield more information on the hazardous lakes.

The case of man-made disaster and GLOF termed as a 'Himalayan tsunami', happened at Kedarnath, India can be taken as a lesson to minimize potential loss. The techniques adopted at potentially dangerous glacier lakes, monitoring and retreat method will help to reduce chances of outburst of glacier lakes and its vulnerability in Nepal. Thus, it is strongly recommended to pay careful attention to $\operatorname{GLOF}(\mathrm{s})$ to avoid unexpected hazard(s) for water resource development and construction of infrastructures in the high Himalayan regions in Nepal.

\section{Acknowledgement}

The author is grateful to Prof. Dr. Abdul Quaiyum and Dr. Umesh Prasad Shrivastava
(Associate Professor) of Thakur Ram Multiple Campus, Birgunj for their guidance and backstopping during preparation of this article. The author is also thankful to Ms. Moyra Clare Hawkes, VSO to Nepal for her kind support to finalize this paper. Thanks are due to Mr. Shreyash for his kind help in typing the manuscript.

\section{References}

Central Bureau of Statistics. (2011). National population and housing census 2011, National report (2012). Kathmandu: National Planning Commission Secretariat.

Chaudhary, R. P. (1998). Biodiversity in Nepal. Retrieved on December 21, 2014, from http:// unfccc.int/resource/docs/cop7/13ao2.pdf.

Embleton, C. (1989). Natural hazards and global change, ITC Journal 1989, Vol. 3/ 4, 169-178.

Gurung, J. B. (2064). Concept of environmental education for grade XII. Kathmandu: MK Publishers and Distributors.

Institute of Social and Environmental TransitionNepal (ISET-N). ( 2009). Vulnerability through the Eyes of Vulnerable: Climate Change Induced Uncertainties and Nepal's Development Predicaments, A report prepared by Nepal Climate Vulnerability Study Team (NCVST). Kathmandu, Nepal.

Ives, J. D. (1986). Glacier lake outburst floods and risk engineering in the Himalayas. (Occasional Paper No. 5). Kathmandu: ICIMOD.

Kattelmann, R. (2003, January). Glacial lake outburst floods in the Nepal Himalaya: A manageable hazard. Natural Hazards, Vol. 28, Issue 1: 145-154.

LIGG/ WECS/ NEA. (1988). Report on first expedition to glaciers and glacier lakes in the Pumqu (Arun) and Poiqu (Bhote-Sun Koshi) river basins, Xizang, Tibet-China. Retrieved on December 15, 2014 from https://www.scribd. $\mathrm{com} / \mathrm{doc} / 72464520 /$ Indus-Basin 
Retrieved on 25 December, 2014 from $w w w . n a t-$

North India Flash floods (2013). Retrieved on December 27, 2014. http://en.wikipedia.org/ wiki/kedarnath.

SAAPE, (2010). Poverty and vulnerability cycles in South Asia: Narratives of survival and struggles. Kathmandu: Author.

Sharma, P. K. \& Bhatta, B. (2008). Environmental Education. Kathmandu: Bhundipuran Publication.

(2011). Environmental Education. Kathmandu: Bhundipuran Publication.

Shrestha, B. B., Nakagawa, H., Kawaike, K., Baba, Y. \& Zhang, H. (2013). Glacial hazards in the Rolwaling valley of Nepal and numerical approach to predict potential outburst flood from glacial lake. Landslides 10(3):299-313.

Singh, S. (1999). Environmental Geography. Allahabad: Prayag Pustak Bhawan, India.

Singh, V. P. \& Haritashya, U. K. (2008). Encyclopedia of snow, ice and glaciers. hazards-eurtht-syst-sci.net/8/1329/2008/.

Strahler, A. N. \& Strahler, A. H. (1976). Geography and Man's Environment. New York: John Willey.

UNFCCC. (2001). United Nations Framework Convention on Climate Change. Retrieved on 22 December, 2014. Wikipedia.org.

Water and Energy Commission Secretariat. (1987). Preliminary study of glacier lake outburst floods in the Nepal Himalaya. Phase I Interim Report. Kathmandu: Author.

Yamada, T. (1991). Preliminary work report on glacier lake outburst flood in the Nepal Himalayas. WECS Report No.4/1/291191/1/1 Seq. No. 387 .

Yamada, T. (1992). Report for the first research expedition to Imja Glacier Lake. WECS Report No. 3/4/120892/1/1 Seq. No. 412.

Yamada, T. (1998). Glacier lake and its outburst flood in the Nepal Himalaya. Data Center for Glacier Research, Japanese Society of Snow and Ice, Monograph, 1:1-96. 